\title{
Manufacturing and Dismantling Territories in Turkey: Between Unitarist Ideology and Obsession for Profit
}

Ségolène Débarre and Jean-François Pérouse

\section{OpenEdition}

\section{Journals}

Electronic version

URL: http://journals.openedition.org/ejts/6191

DOI: 10.4000/ejts.6191

ISSN: $1773-0546$

Publisher

EJTS

Electronic reference

Ségolène Débarre and Jean-François Pérouse, « Manufacturing and Dismantling Territories in Turkey: Between Unitarist Ideology and Obsession for Profit », European Journal of Turkish Studies [Online], 23 2016, Online since 18 November 2019, connection on 24 November 2020. URL : http:// journals.openedition.org/ejts/6191; DOI : https://doi.org/10.4000/ejts.6191

This text was automatically generated on 24 November 2020.

(c) Some rights reserved / Creative Commons license 


\title{
Manufacturing and Dismantling Territories in Turkey: Between Unitarist Ideology and Obsession for Profit
}

\author{
Ségolène Débarre and Jean-François Pérouse
}

1 In a context where the difficulties of in situ research are accumulating and where it can be delicate locally to free oneself from an activist agenda, this issue opens up a project, that of analyzing discursive practices and policies regarding Territory in Turkey. The latter, characterized by a dual nature, both material and symbolic, can be understood in a first approach, as a complex of singular places, a differentiated physical space collectively instituted, and the object of representations and modes of appropriation that are often contradictory and evolving. The conflicts and confrontations between divergent conceptions and appropriations of territory have multiplied and have been violently exacerbated in recent years - from suppressed demonstrations on one side of the country to military conflict on the other.

2 Territory, as a differentiated space, is obscured by the exaltation of the mother country and the unitarian ideology of the nation on the one hand, and by predatory land ownership practices on the other, the two poles of the current creation of territory. What is common, a priori, between them? Definitely an isotopy ideal. The unitarian ideology as well as the obsession with profit organize space according to a homogeneous order: the "complex of singular places" and "the differentiated physical space" give way to a space conceived as similar. They annihilate "other places", those that are not compliant and / or not profitable. The heterotopias ${ }^{1}$ and their spaces of expression are dwindled and silenced. Let's see. 

permeates the dominant political culture in Turkey has had the effect of denying the singularities of the territory. Provinces must not be singled out by an idiosyncratic designation, which is why, with a few exceptions, "proper names specifically designating a portion of the territory delimited according to various natural, historical or economic criteria are practically absent from contemporary Turkish" (Bazin, 1986: 17). The toponymy, systematically modified, is in the image of this "new man", the Turkish citizen whom the Republic intended to shape: "Happy is he who can say 'I am Turkish'" [ne mutlu Türküm diyene] chanted the Anatolian hills. The assigned identity is engraved in the landscape. School geography repeats endlessly the great national narrative and sings the unity of the country (Özkan 2014). The mission assigned to the Ministry of Education, from the early days of the Republic and even during the Young Turk period under the influence of French positivists and a certain Enlightenment philosophy, is to give substance to this sacred national unity, by avoiding highlighting the factors of difference and even endeavoring to erase them. If the school makes one love his country, it is the country as a national community that is exalted and not as a "territory" - a socio-spatial configuration that is always differentiated and therefore conflictual $^{2}$.

4 The term "territory" is actually difficult to translate into Turkish: besides the terms toprak (ground/land) or alan (area), the words ülke (country) or vatan (homeland), fairly abstract notions with a strong political affect, are often seen as equivalent. These last two notions may be contained within the present borders of Turkey, or they may refer to a larger area extending to the Chinese border, homeland of the ancestors (Copeaux 1997, Durgun 2011). The term memleket is probably the one that best combines the different political and spatial meanings of territory: it refers to the space on which the power of the sovereign is exercised (from ö / mamlaka (t) / kingdom) but also to the region of origin or identification (the country in the sense of "small homeland"). The notion of territory implies, in contrast to the terms "space" or "area", a political appropriation but also idiosyncrasy, internal differentiation.

recently, following an Anglo-Saxon tendency, the term yer (location / place) crystallizes self-referencing spatial inclinations, appropriating thus one of the attributes of territory (Debarbieux 2003: 912). In reaction to the indifferentialist ideology, which negates the diverse qualities of the territory, and under the percolating effect of international discourses (International Monetary Fund, World Bank, European Union), a new gaze on the local emerged in the $1990 \mathrm{~s}^{3}$ which relies on forms of cultural expression (languages or musical productions claiming local or regional references) as well as a significant development of local history (research, various publications, special collections in national publishing houses) ${ }^{4}$. The political and economic investment of the local reference (often in a very limited way, which does not reach the regional dimension) is illustrated in the instrumentalization of homeland associations [yöresel dernek or hemşehrilik derneği] by different political parties with the objective of collecting votes according to communities of origin ${ }^{5}$. On the economic side, the touristic specialization of the country and the rise of an alternative agriculture (labeled "local") have led to a rediscovery of the positive value of territorial differences. The integration of environmentalist slogans into political and associative discourses, and the demands made by certain international bodies (dispensers of aid) have also had the effect of altering the dominant viewpoint. The local (more than the regional) has become 
"trendy", even marketable. However, the substitution of the terms "local" and "territory" is not self-evident: the Justice and Development Party (AKP) thus made the concept of "local development" [yerel kalkınma] one of the main themes of its electoral program in 2002 and 2004, but the reference to the local had no territorial dimension at that time. It was then just about freeing the mostly economic energies and initiatives from below, against a center accused of imposing its hegemonic, uniformizing and predatory law. For the AKP at the time - which was soon to abandon this slogan - the local was also the traditional, which had supposedly been mauled by previous modernizing republican policies ${ }^{6}$.

6 To question the fabric of territories in contemporary Turkey is to take an interest in the relationship that the State maintains with a space which it intends to control and administer, but also to question the individual and collective appropriations of the places, according to material or symbolic registers, as well as the multiple and nested scales they mobilize. In short, analyzing the tension between the territory in the singular and in the plural. Territorial indivisibility remains a key value of Turkish political discourse, and the semantic shift from the term "region" [bölge] to the hated term "separatist" [bölücü] is constantly dreaded7. To divide the territory into regions (beyond a natural classification) ${ }^{8}$, to identify regional sub-areas that might possibly be given specific administrative powers is, in one way or another, a potential threat to the unity of the homeland. The fear is such that the term "regional" [bölgesel] was finally removed from the name of the "development agencies" [kalkınma ajanslari] created in 2006 (Bayraktar and Massicard 2011; Montabone 2011).

Illustration 1

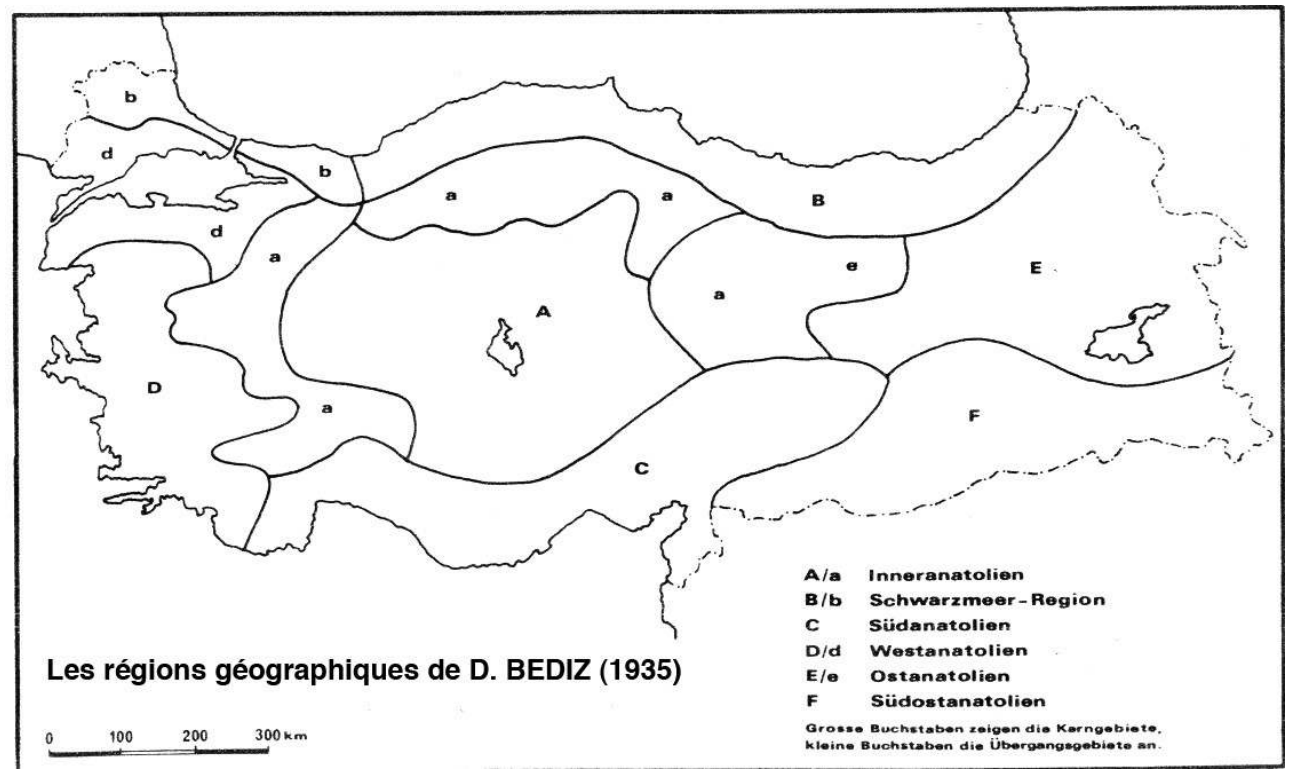

The division into "natural" geographic regions by Danyal Bediz (1935).

7 Although the 1921 Constitution had provided for the creation of "general inspection areas" for the maintenance of order (Yerasimos 1988: 116), the design of the region was clear, recalling that of the provincia in the Latin sense, which is a controlled, gridded 
and dominated territory. And the settlement laws of 1934 and 1936 only reinforced this approach, as the State sought to repopulate - after the hemorrhage of the First World War ${ }^{9}$, the Greco-Turkish War and the population exchange of 1923-192410 - and to homogenize the territory, in disregard of cultural and linguistic differences, by displacing certain populations deemed unreliable, or at least suspicious a priori, and by substituting with other, supposedly safer ones. The linguistic and political homogenization of the national territory was then one of the main objectives ${ }^{11}$, even though security policies had from the beginning of the history of the Turkish Republic contributed to individualizing a Kurdish region - which was constantly redefined without naming $\mathrm{it}^{12}$, by the mere control devices and exception status prevailing there ${ }^{13}$. The military approach thus has the effect of smoothing the territory, perceived as a whole, where the presence of the State must be everywhere perceptible and felt.

8 Although the Directorate General for Planning and Development of the new Ministry of Public Works was entrusted in 1958 with the task of establishing "Regional Planning Plans", and while the 1961 Constitution had approved the principle of decentralization, the planning agencies created at that time (including the State Planning Agency, Devlet Planlama Teşkilatı or DPT in $1960^{14}$ ) and the beginning of the five-year plans (Kansu 2004) in fact reinforced centralizing administrative practices. Planning is primarily macroeconomic and developed by engineers and senior civil servants in Ankara who think of the country as a whole without its nuances ${ }^{15}$. The establishment in 1994 of a "Directorate General for Regional Development and Structural Harmonization" within the DPT seems to be above all a response to European demands - regularly seen as a threat to the integrity of the country - and did not mark a real change in the perception of the territory. The sectional logic of state intervention in the national territory has had the effect of denying regional logics (Dericioğlu 1989: 10). It was only with the 5th Five-Year Plan that a more "territorially integrated" dimension emerged: in 1982, the DPT proposed the constitution of 16 functional regions and established "regional development schemes" without however any associated public policy (Bayraktar and Massicard 2011: 39). It is not until the $7^{\text {th }}$ Plan (1996-2000) that "the need to combine sectional development and spatial analysis" was affirmed for the first time (Dulupçu 2005: 110).

9 The territorial divisions of Republican Turkey have methodically sought to blur the boundaries of pre-existing cultural, linguistic or religious units. The twelve administrative regions created in 2003 (NUTS 1) also follow this principle, thus carefully avoiding the clustering of Kurdish-majority lands into a single entity ${ }^{16}$ (Figure 2). 
Illustration 2

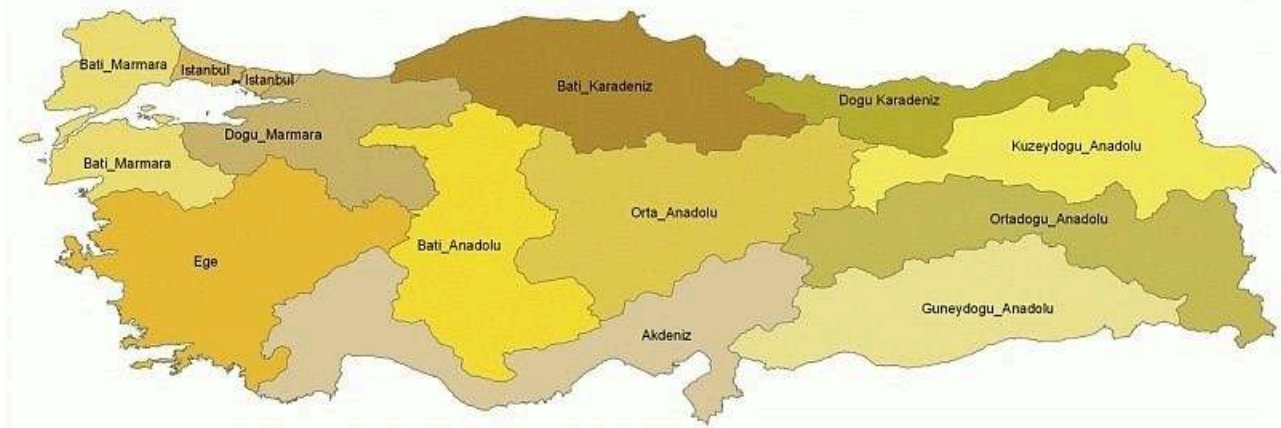

The twelve regions created in 2003.

Pascal Lebouteiller/IFEA, 2005.

Illustration 3

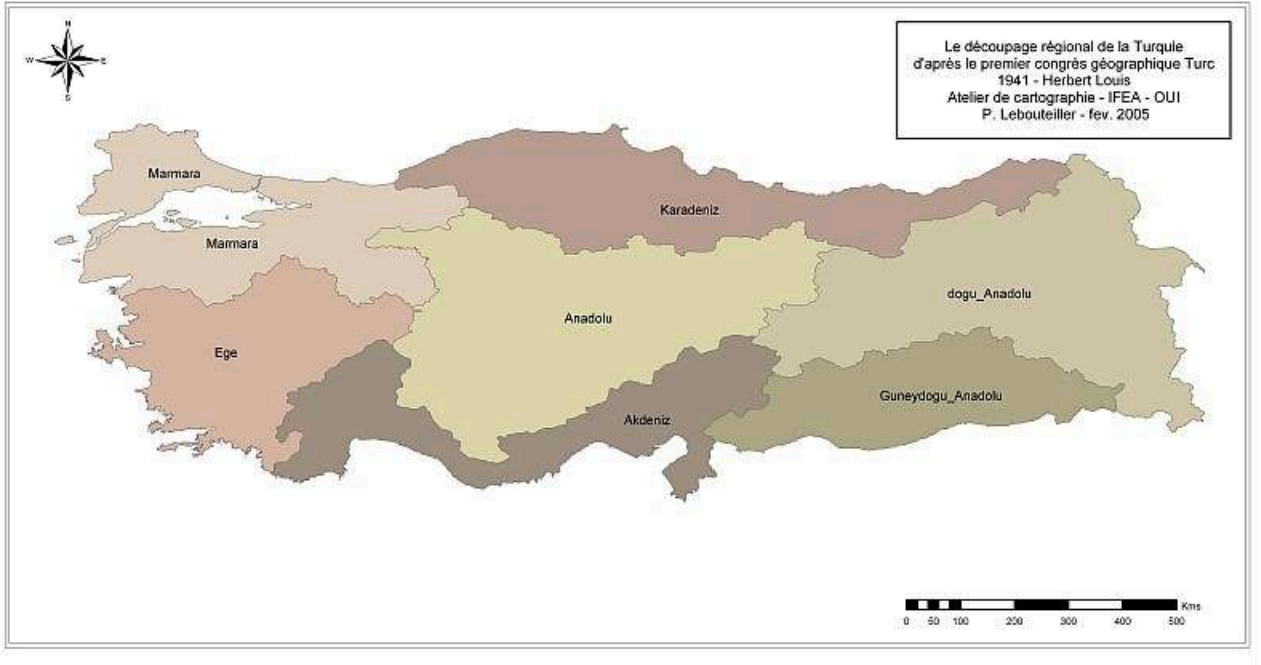

The regional division into seven areas from 1941 to 2002

Pascal Lebouteiller/IFEA, 2005. 

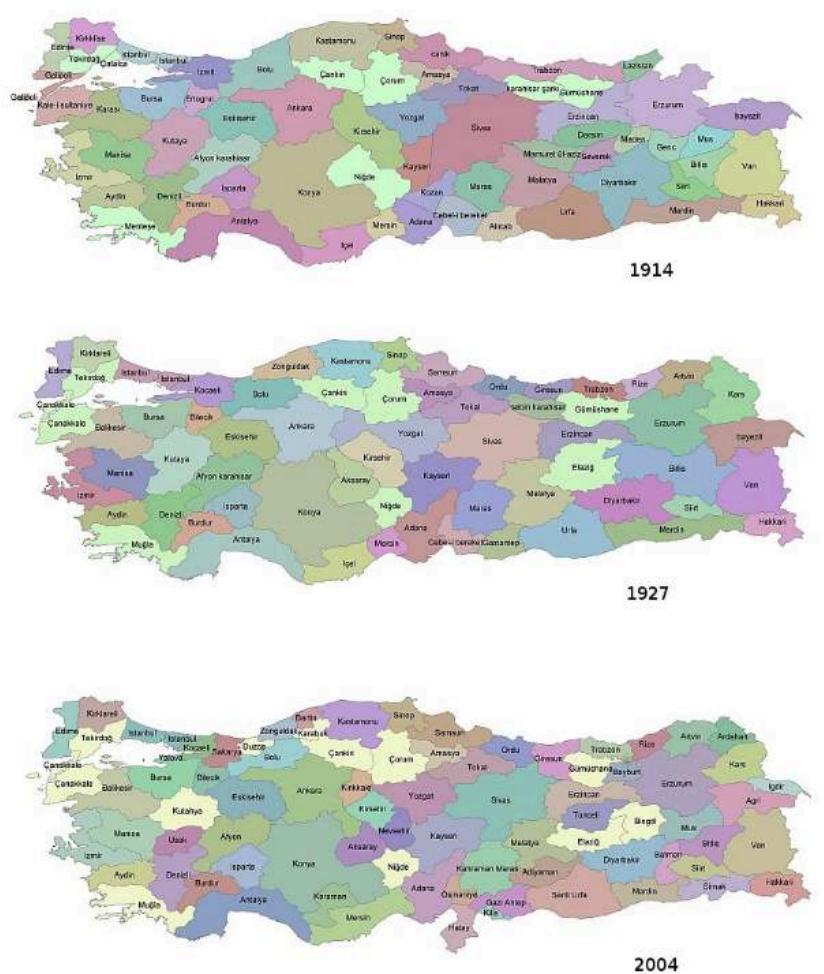

Evolution of departmental divisions from 1914 to 2004 (NUTS-3).

Pascal Lebouteiller/IFEA, 2005

10 For the time being, the region remains essentially a statistical framework, "offered" to European bodies in order to capture material resources such as structural funds ${ }^{17}$. Article 1 of Law No. 5449, which sets the objective for development agencies "[...] to accelerate regional development, strengthen its sustainability and reduce development differences within regions" does not seem to take explicit account of the differences between regions and so far "little progress has been made in reducing inequalities" and in some cases even "inequalities have been widening" (Bayraktar and Massicard 2011: 47). Competition between ministries and/or central administrations sometimes contributes negatively to this situation. Each administration, each ministry has its vision of the territory and its way of subdividing it for its own purposes: the vision of the DPT (planning) it not that of the DSI (hydraulic policy), which is not that of yet another ministry. And in recent years, the increased power granted to metropolitan municipalities has complicated the situation further.

The urbanization of the country (in 1985, according to official statistics, the Turkish population became predominantly urban), the consolidation of local authorities reinforced by the Municipal Act of 1984, the focus of public and private investments on large cities, the growth of international tourism, the crisis of national planning, etc., can be read as symptoms of a change of paradigm regarding territory. After the reforms of the 1980s, the March 2008 law cancelling the municipal status for towns with less than 2000 inhabitants, that of July 2008 on the increase of financial resources 
for local authorities, and especially the November 2012 law (5779) on new metropolitan municipalities, the power of metropolises has been significantly strengthened (Pérouse 19/11/2012). Changes in their perimeters have also led to a partial overlap between authorities: for example, the limits of Greater Istanbul correspond today with those of the department, in this case ending competition between the department and metropolitan authorities to the benefit of the latter, but leading to quarrels and rivalries in other cases. Whatever the situation, this metropolitanization has an impact on the management of peri-urban resources, in particular water or rural spaces. Municipalities, and in particular the fifteen metropolitan municipalities, have gained increasing influence since the 1980s, including the right to draw up and revise urbanism plans which led to the development of urban land as investment, attracting investors who were then eager to enter municipal councils.

Since the early 2000s, the governance of the AKP has considerably strengthened the concept of land as investment - a more or less vast space of momentary opportunities, desires, ostentation, and the confrontation of personal interests. The territory is the product of the urban project or transport infrastructure: it multiplies with the expansion of land suitable for building development and the recovery of military land (increased since July 2016). Failure to take into account the collateral, and in particular, environmental effects of these projects is obvious, as their compulsive and precipitated character is equal to the hoped-for gains, irrepressible "fix" of capital, indifferent to alternative solutions and long-term consequences. The territory then becomes primarily an object of "marketing" [markalaşma] whose theories and manuals have become essential reading for municipal planners ${ }^{18}$. The article by Bilge Serin in this issue shows, from an empirical analysis of press clippings, the way in which closed gated communities are sold to the public in Turkey. Analyzing the advertising discourse, the article postulates a certain level of social consensus allowing the success of these real estate projects and the transformation of the very concept of urbanity.

In front of this consensus, which is still too little studied ${ }^{19}$, the forms of resistance and contestation, direct or not, have taken on multiple faces and hybridized with locally reinvented transnational mobilizations (\#occupy). An example of this is the cultivation of soil for urban vegetable gardens (bostan) studied by Agathe Fautras in central Istanbul (Beyoğlu, Kadıköy, Üsküdar). Following the so-called Gezi mobilization in 2013, such gardens were created in urban interstitial spaces, as a sign of resistance: the collectives behind these initiatives denounced the commodification of land and the absence of environmental considerations on the part of the Turkish Government. The "hopes contained in the utopia of the gardener" as in Gilles Clément's nice formula (Clement and Jones 2006) have been encountering, first of all, the obstacles and aversion of the administration. Secondly, the struggle for their perpetuation makes them run the risk of being hijacked for political purposes, thus somewhat minimizing their asperities and singularities: an absorption of heterotopia in the isotopy, in short.

Unlike these "protest gardens", the design of municipal parks clearly reflects their adherence to a form of social control promoted by the government. Since 1994, the parties of Turkish political Islam and since 2003 the AKP, in a much more marked way, have indeed the ambition to produce new territories, "informing" "the individual and the collective on their identity" ${ }^{20}$ - as, in its day but in another way, the Kemalist city intended to create the new citizen (Bozdoğan 2001). Henceforth, it is the integration of the religious and the de-facto revocation of the secularization enterprise that takes 
precedence. The moralization of urban space, described in Helin Karaman's article on the recent "Topkapı culture park" (Topkapı Kültür Parkl) in Istanbul, is inseparable from a growth in the control and privatization of public space (in this case, handing over the surveillance of the park to private security firms, the same ones that carefully guard the shopping malls that have multiplied in the city over the past fifteen years). Reflecting the leisure activities of the middle and popular classes, the park participates in an urban project aiming to create standardized places, in conformity with a normalized modernity.

However, beware of the risks of essentialization and of using common explanatory schemes. The temptations are twofold: on the one hand, the mobilization of critical references on space (in particular Foucault, Lefebvre, Harvey) has been systematized in Turkey - at the risk of an in-fine acritical convention and the construction of a great universal narrative on the a priori functioning of a "neo-liberal city". On the other hand, and paradoxically, Islamity seems to situate the territorial project in an irreducibly local and singular space. Yet, research does not address the articulation between these two poles of discourse, the postulate of the particular and of the universal. In many respects, the current territorial paradigm in Turkey, beyond the Islamist veneer, could usefully be compared to a Chinese model of territorial administration: big projects, patrimonial and ecological brutality, eradication of disputes, belief in the omnipotence of technology, support from an emerging middle class, etc., very much at odds with the democratic discourse of contemporary Europe, which is all about "participation" and "collaboration". The resemblances are indeed numerous:

In China [as today in Turkey], the definition of the city is broad and also includes the neighboring rural area. This was reinforced by the reforms of the early 1980 s. The Chinese city is above all a space of power that controls a territory, whether urban or rural. The so-called Chinese municipalities have rural districts and can contain villages, hamlets and small towns (Sanjuan 2013).

In the same perspective as in China, regardless of the ecological costs, urbanization is conceived in Turkey as an essential engine of growth and an instrument of "modernization" for the country. In this perspective, reforms, practices and discourses are currently converging in Turkey and China. Even the "neo-Ottoman" style which currently appears in Turkish public space, and which one would be tempted to inscribe in a strictly autochthonous dynamic, resonates with the "Chinese-style pastiches" promoted by some municipalities of the People's Republic ${ }^{21}$. Without doubt, in both cases, cities are the places where national identity is redefined, with the aim of a smooth organization of the national territory alongside a homogenization of the social body.

However, this homogenization is stalled for now. The article by Sylvain Cavaillès, in this issue - Kurdistan Heterotopia: defense and illustration of a literary territory - presents, through the case of Kurdish writers from Turkey, this "intricacy of language and territory questions" and the "linguistic schizophrenia" in which spaces with a Kurdish majority are experienced and thought of. Prohibition, in territorial matters, is thus as much the hindrance to physical movement - neighborhoods evacuated by urban transformation, roads barred for security reasons, borders closed following diplomatic crises $^{22}$ - than an impossible formulation, in cartographic ${ }^{23}$ or verbal form: can we say 
territory? In which language and with which words? Thanks to the (temporary?) flowering of publishing houses, magazines and dedicated websites, the literary territory offers a space of resilience and makes it possible to express absence: the "absent place" (Cavaillès' translation of the expression "yokyer" by the artist-writer şener Özmen) is not the "non-place", the "interchangeable" place, it is an "off-map" place, a heterotopia which meets the fate of other minorities, Syriac or Armenian. The territory is here understood as a complex of singular places (embodied by geographies such as mountains or borders) and among them, the real or invented city - Mardin, Diyarbakır - which is the main support for self-referencing and identification.

The high proportion of Turks who come from territories outside of Turkey (Balkans, Crimea, Caucasus, etc.), the intense movement of inhabitants on the national territory, and the ease with which one claims to have several places of origin at the same time, redefine a territory which is no longer a delimited set of places separated by fixed, irreducible distances, but a stratified space, with contours that vary in time and according to individuals, a complex product of mobility strategies. Such a focal point avoids the "temptation to bring territory back to spatial continuity alone - an avatar of political modernity and its own conception of territoriality" (Debarbieux 2003: 912). The new porosities and uncertainties created by the war in Syria have also aroused or revived a feeling of belonging to transnational regions (Montabone 2016), such as the Kurdish, Yezidi or Turkmen identities. Furthermore, the settlement of the refugee populations of Iraq and Syria, and the formation of diasporas, have led to territorial upheavals, particularly in the southern regions and major cities of the country, especially in Istanbul, which are not analyzed in this issue and will be part of a future publication.

\section{BIBLIOGRAPHY}

Acı, Esra Yüksel (2005). Kalkınma Sürecinin Yeni Aktörleri Sivil Toplum Kuruluşları, Istanbul, Günizi.

Aydın, Suavi (2005). “Bir Tilkinin Ettiği: İsimler Millî Birliği Nasıl Bozar?”, Toplumsal Tarih 143, p. 90-97. URL : http://www.birikimdergisi.com/guncel-yazilar/1001/bir-tilkinin-ettigi-isimlermilli-birligi-nasil-bozar\#.WF07GW7YWUk.

Bayraktar, Ulaş ; Massicard, Élise (2011). « La décentralisation en Turquie », Focales 7, Paris, Agence Française de Développement. URL : http://www.afd.fr/jahia/webdav/site/afd/shared/ PUBLICATIONS/RECHERCHE/Scientifiques/Focales/07-Focales.pdf.

Bayraktar, Ulaş (2007). "Turkish municipalities: Reconsidering local democracy beyond administrative autonomy”, European Journal of Turkish Studies. URL: http://ejts.revues.org/ 1103.

Bazin, Marcel (1986). « Les disparités régionales en Turquie », in Gökalp, Altan (dir.), La Turquie en transition : disparités, identités, pouvoirs, Paris, Maisonneuve-Larose, p. 17-47. 
Bazin, Marcel (1991). « Disparités et déséquilibres régionaux », in Dumont, Paul ; Georgeon, François (dir.), La Turquie au seuil de l'Europe, Paris, L'Harmattan, p. 23-45.

Bazin, Marcel (1994). «L'ouverture des campagnes », in Yerasimos, Stéphane (dir.), Les Turcs, Paris, Autrement, p. 79-85.

Bazin, Marcel (2000). « La région, cette inconnue... Réflexions sur l'identité régionale dans le monde turco-iranien », in Balland, Daniel (dir.), Hommes et Terres d'Islam. Mélanges offerts à Xavier de Planhol, Tome II, [Bibliothèque Iranienne 53], Téhéran, Institut Français de Recherche en Iran (IFRI), p. 345-358.

Bazin, Marcel (2005). « Diversité ethnique et disparités régionales », in Vaner, Semih (dir.), La Turquie, Paris, Fayard, p. 389-428.

Bora, Tanıl (dir.) (2005). Taşraya Bakmak, Istanbul, İletişim.

Bozarslan, Emîn (1966) Doğu'nun Sorunları, Istanbul, Avesta.

Bozarslan, Hamit (1997). La question kurde. États et minorités au Moyen-Orient, Paris, Presses de Sciences Po.

Bozdoğan, Sibel (2001). Modernism and Nation Building. Turkish Architectural Culture in the Early Republic, Washington, Washington University Press.

Clément, Gilles ; Jones, Louisa (2006). Une écologie humaniste, Genève, Aubanel.

Copeaux, Étienne (1997). Espaces et temps de la nation turque. Analyse d'une historiographie nationaliste, 1931-1993, Paris, CNRS Éditions (traduit en turc, Istanbul, Tarih Vakfı Yurt Yayınları, 1998).

Darkot, Besim (1995). “Türkiye'nin Coğrafi Bölgeleri Hakkında”, Türk Coğrafya Dergisi, (13/14), p. 141-150. URL : http://dergipark.ulakbim.gov.tr/tcd/article/view/1074000641.

Debarbieux, Bernard, (2003). « Territoire » in Lévy, Jacques ; Lussault, Michel (dir.) Dictionnaire de la géographie et de l'espace des sociétés, Belin, Paris, p. 910-912.

Dericioğlu Taylan (1989). “Güneydoğu Anadolu Projesinin Ekonomik ve Sosyal Etkileri” , in Ekonomik ve Sosyal Etüdler Konferans Heyeti, Türkiye'de Bölgesel Politika, Istanbul, Acar, p. $110-19$.

Doğan, Sevinç (2016). Mahalledeki AKP, Parti İşleyişi, Taban Mobilizasyonu ve Siyasal Yabancılaşma, Istanbul, İletişim.

DPT (Devlet Planlama Teşkilatı) (1982). Türkiye'de Yerleşim Merkezlerinin Kademelenmesi, 2 vol. , Ankara, DPT.

Durgun, Sezgi (2011). Memalik-i şahane'den Vatan'a, Istanbul, İletişim.

Eliçin-Arıkan, Yeşeren (1997). « Municipalités métropolitaines et d'arrondissement en Turquie », Cahiers d'Études sur la Méditerranée et le monde turco-iranien 24, p. 71-104. URL : https:// cemoti.revues.org/1463.

Eliçin-Arıkan, Yeşeren (1997). Décentralisation et urbanisme en Turquie, Thèse de Doctorat en urbanisme sous la direction de Jacques Bourdon, Université de droit, d'économie et des sciences d'Aix-Marseille III, Institut d'Aménagement Régional.

Eraydın, Ayda (1983). Approaches to Regional Development in the Planned Period, Ankara, SPO.

Erder, Necat; Karaosmanoğlu, Atilla; Sönmez, Atilla; Çilingiroğlu, Ayhan (2003). Plânlı Kalkınma Serüveni, Istanbul, Istanbul Bilgi Üniversitesi Yayınları. 
Erinç, Sırrı (1958). “Bölge Sınırlandırılmasının Esasları”, İskân ve şehircilik Haftası Konferansları, Siyasal Bilgiler Fakültesi Yay. 9, p. 103-114.

Erinç, Sırrı (1959). “Bölge Plânı Nasıl Yapılır?”, Istanbul Üniversitesi Coğrafya Enstitüsü Dergisi 10, p. 36-51. URL : http://aves.istanbul.edu.tr/ImageOfByte.aspx?Resim=8\&SSNO=13\&USER=4150.

Erol, Oğuz (1983). Die naturraümliche Gliederung der Türkei, Wiesbaden, L. Reichert.

Foucault, Michel (1967). « Des espaces autres », Dits et écrits (1984), tome IV, Paris, Gallimard, p. 752-762.

Gökalp, Altan (1986). « Espace rural, village, ruralité : à la recherche du paysan anatolien », in Gökalp, Altan (dir.), La Turquie en transition. Disparités, Identités. Pouvoirs, Paris, Maisonneuve et Larose, p. 49-79.

Güntekin, Reşat Nuri (1936). Anadolu Notları, vol. 1, Istanbul, İnkilâp ve Aka Kitabevleri.

Heper, Metin (1989). Local Government in Turkey. Governing Greater Istanbul, London, Routledge.

Heper, Metin (1987). Democracy and Local Government. Istanbul in the 1980's, Walkington (UK), Eotehne Press.

Jongerden, Joost (2007). The Settlement Issue in Turkey and the Kurds, Leiden \& Boston, Brill. DOI : $10.1163 / 157338410 X 12625876281703$.

Kansu, Günal (2004). Planlı Yıllar (anılarla DPT’nin öyküsü), Ankara, İş Bankası.

Keleş, Ruşen (1996). Kentleşme Politikası, Ankara, İmge.

Keyder, Çağlar (1996). Ulusal Kalkınmacılığın İflası, 2e édition, Istanbul, Metis.

Kadirbeyoğlu, Zeynep; Özertan, Gökhan (2015). "Power in the Governance of Common-Pool Resources: A Comparative Analysis of Irrigation Management Decentralization in Turkey", Environmental Policy and Governance 25 (3), p. 157-171. DOI : 10.1002/eet.1673.

Köymen, Nusret Kemal (1934). “Soy Düzeni”, Ülkü 4, p. 302-303.

Köymen, Nusret Kemal (1935). “Köycülük Programına Giriş”, Ülkü 5 (26), p. 132-141.

Köymen, Nusret Kemal (1937). Village, the Unit of Societal Organization, Master's thesis, Wisconsin, Wisconsin University.

Köymen, Nusret Kemal (1948). Bölge Plancılığı, Memleket Kalkınması, Istanbul.

Loewendahl-Ertugal, Ebru (2005). "Europeanisation of Regional Policy and Regional Gouvernance: The Case of Turkey", European Political Economy Review 3 (1), p. 18-43. URL: http://aei.pitt.edu/ 6094/1/loewendahl.pdf.

Louis, Herbert (1985). Landeskunde der Türkei. Vornehmlich aufgrund eigener Reisen, Geographische Zeitschrift, Beihefte, Wiesbaden, F. Steiner.

Massicard, Élise (2001). « Sivas, une province turque entre local et global », Les Études du CERI 79, Paris, Sciences Po. URL : http://spire.sciencespo.fr/hdl:/2441/rmmq6777o8msohlgt9pdgv2lk.

Massicard, Élise (2005). « Politiser la provenance. Les organisations d'originaires de Sivas à Istanbul et Ankara », European Journal of Turkish Studies 2. URL : http://ejts.revues.org/362.

Mercan, Faruk (2004). “Devlet Planlama Kulübü”, Aksiyon, Haziran, p. 54-58. 
Montabone, Benoît (2011). La cohésion territoriale en périphérie de l'Union européenne : les enjeux du développement régional, Thèse de doctorat en Géographie sous la direction de Guy Baudelle, Université Rennes 2.

Montabone, Benoît (2016). “The Wartime Emergence of a Transnational Region between Turkey and Syria (2008-2015)” in Vignal, Leilla (dir.), The Transnational Middle East. People, Places, Borders, Londres, Routledge, p. 181-197.

Mutluer, Mustafa (2009). «Inégalités interrégionales en Turquie et études de planification régionale » in Les vertus de l'interdisciplinarité. Mélanges offerts à Marcel Bazin. Les Cahiers de L'IATEUR, Nº Spécial, p. 111-128.

Öktem, Kerem (2003). “Creating the Turk's Homeland: Modernization, Nationalism and Geography in Southeast Turkey in the late $19^{\text {th }}$ and $20^{\text {th }}$ Centuries", in Socrates Kokkalis Graduate Workshop, The City: Urban Culture, Architecture and Society. URL: http://file.setav.org/Files/ Pdf/creating-the-turk\%E2\%80\%99s-homeland-modernization-nationalism-keremoktem-2003.pdf.

Öktem, Kerem (2005). Reconstructing Geographies of Nationalism: Nation, Space and Discourse in Twentieth Century Turkey, PhD thesis, University of Oxford.

Öktem, Kerem (2009). “The Nation's Imprint: Demographic Engineering and the Change of Toponymes in Republican Turkey”, European Journal of Turkish Studies 7, URL: http:// ejts.revues.org/2243.

Özkan, Behlul (2014). "Making a National Vatan in Turkey: Geography Education in the Late Ottoman and Early Republican Periods”, Middle Eastern Studies 50 (3), p. 457-481. DOI :

10.1080/00263206.2014.886569.

Öztürkmen, Arzu (1998). Türkiye'de Folklor ve Milliyetçilik, Istanbul, İletişim.

Payzın, Ziya (1967 ?). Türkiye'de Yerleşim Sorunları ve Bölgeler Arası Dengesizlikler, Ankara, Nuve.

Pérouse, Jean-François (1998). « Naissance nationale et naissance urbaine (Ankara/Islamabad) : de l'inconstruit au mal- ou déconstruit », in Eveno, Emmanuel (éd.), Villes et Territoires, Utopies Urbaines, Toulouse, CIEU/CNRS/PUM, p. 21-40.

Pérouse, Jean-François (2002). « Istanbul et l'État turc. La métropole contre l'État ? », in Le pouvoir et la ville à l'époque moderne et contemporaine, Collection KUBABA, Série Actes I, Université de Paris I /Institut Catholique de Paris, Actes du colloque « La ville au cœur du pouvoir » Paris 7-8 décembre 2000, vol. 2, p. 219-242.

Pérouse, Jean-François (2003). « La difficile affirmation des villes moyennes turques comme symptôme de dysfonctionnements politico-économiques ", in Charbonneau, François ; Lewis, Paul ; Manzagol, Claude (dir.), Villes moyennes et mondialisation, renouvellement de l'analyse et des stratégies, Actes du colloque international, Université de Montréal, du 18-20 septembre 2002, Montréal, Trames/UM, p. 92-99.

Pérouse, Jean-François (2005). « Phénomène migratoire, formation et différenciation des associations de hemşehri à Istanbul : chronologies et géographies croisées ", European Journal of Turkish Studies 2. URL : https://ejts.revues.org/369.

Pérouse, Jean-François (2010). “İstanbul'un Eski Çeperlerinde Yeni Bir 'Kentsel Kimlik' Yaratma Çabası : Yerel Adil Düzen'den Küreselleşen Piyasa Arayışlarına. Başakşehir Hikâyesi (1995-2008)”, in Turgut Yıldız, Hülya ; Eyüce, Ahmet (dir.), Kent, Kültür, Konut - Bildiri Kitabı, IAPS-CSBU 
Network, Kültür ve Mekan Toplantıları, Ulusal Sempozyum 1, Istanbul, Bahçeșehir Üniversitesi, p. 24-28.

Pérouse, Jean-François (19/11/2012). « La création de 13 nouvelles municipalités métropolitaines en Turquie par la modification de la loi $n^{\circ} 5779$ ou le triomphe écrasant de l'urbain dans l'ordre de gestion territoriale », Dipnot. URL : http://dipnot.hypotheses.org/37.

Pérouse, Jean-François (27/01/2014). « Après les élections locales du 30 mars 2014, 16000 villages vont être rayés de la carte », Dipnot. URL : http://dipnot.hypotheses.org/464.

Pınarcıoğlu, Melih ; Işık, Oğuz (s.d.). Yeni Kalkınmacılık: Bölgesel Kalkınmada Arayışlar, Ankara, GAP-GIDEM.

Pınarcıoğlu, Melih ; Işık, Oğuz (2005). "Prof. Dr GERAY ile Söyleși”, Planlama 2, Ankara, p. 4-22.

Sanjuan, Thierry (2013). «La ville chinoise est un espace de pouvoir », Entretien avec Thierry Sanjuan réalisé par Charlotte Ruggeri et Léo Kloeckner, Revue Urbanités. URL : http:// www.revue-urbanites.fr/entretien-thierry-sanjuan-la-ville-chinoise-est-un-espace-de-pouvoir/. Sauner-Nebioğlu Marie-Hélène (1995). Évolution des pratiques alimentaires en Turquie : Analyse comparative, Berlin, Klaus Schwarz.

Sönmez, Abdulkerim (2008). "The Effects of Violence and Internal Displacement on RuralAgrarian Change in Turkey", Rural Sociology, 73 (3), p. 370-413. DOI :

10.1526/003601108785766534.

Sönmez, Mustafa (1998). Bölgesel Eşitsizlik, Istanbul, Alan.

Staszak, Jean-François ; Lussault, Michel (2003). « Hétéropie », in Lévy, Jacques ; Lussault, Michel (dir.), Dictionnaire de la géographie et de l'espace des sociétés, Paris, Belin, p. 452-453.

Tapia, Stéphane de (1991). « Aménagement hydraulique et aménagement du territoire en Turquie ", in Milieux calcaires et politique hydraulique, $115^{\mathrm{e}}$ Congrès National Des Sociétés Savantes, Avignon 1990, Paris, CTHS, p. 159-168.

Tekeli İhlan (1981). “Dört Plan Döneminde Bölgesel Politikalar ve Ekonomik Büyümenin Mekansal Farklılaşması”, ÖDTÜ Gelişme Dergisi, “Planlama” Özel Sayısı, p. 369-389.

Thevenin, Michaël (2014). « De la pastoralité dans l'Est de la Turquie », Revue de géographie alpine 102 (2), URL : http://rga.revues.org/2469.

Tuncel, Metin (1960). “Türkiye Coğrafi Bölgelerin Ziraî Karakterleri”, İstanbul Üniversitesi Edebiyat Fakültesi Coğrafya Enstitüsü Dergisi 11, p. 76-101.

Tunçel, Harun (2000). “Türkiye'de İsmi Değistirilen Köyler”, Firat Üniversitesi Sosyal Bilimler Dergisi 10 (2), p. 23-34. URL : http://cografya.bilecik.edu.tr/Dosya/Arsiv/ Harun\%20Tun\%C3\%A7el\%20Makaleler/ T\%C3\%BCrkiye\%E2\%80\%99de\%20\%C4\%B0smi\%20De\%C4\%9Fi\%C5\%9Ftirilen\%20K\%C3\%B6yler.pdf. Yerasimos, Stéphane (1988). «La planification de l'espace en Turquie », Revue du Monde Musulman et de la Méditerranée, 50 (4), p. 109-122. URL : www.persee.fr/doc/ remmm_0035-1474_1988_num_50_1_2257.

Yerasimos, Stéphane (2005). «L'obsession territoriale ou la douleur des membres fantômes », in Vaner, Semih (dir.), La Turquie, Paris, Fayard, p. 39-60.

Yıldız, Ömer (2001). "Bölgesel Eşitsizlik: Türkiye Örneği”, Atatürk Üniversitesi, İBF Dergisi 15 (1-2). URL : http://e-dergi.atauni.edu.tr/atauniiibd/article/view/1025003504. 
Yıldırım, Selâhattin ; Emrealp, Sadun ; Duben, Alan (1988). Metropolitan Government in Istanbul, Istanbul, Metropolitan Municipality of Greater Istanbul and IULA-EMME.

\section{NOTES}

1. Not in a Foucauldian sense of "crisis heterotopias" or "deviation" (Foucault 1967) but in a postFoucauldian interpretation, namely "singular places of identity and belonging" (gender, ethnic, etc.) as developed in Anglo-Saxon cultural studies.

2. One could draw a parallel between the proclaimed will to deny (or overcome) social classes in the national community and to deny local differences. The citizen [vatandaş, yurttaş] is a deterritorialised figure, which is part of the political space of the nation and of the national community, much more than in a singular environment. Correlatively, the condescension for the villager (the köylï) is part of the same persistent ideology. In the republican imagination of the elites, the villager - and one is now far from the exaltation of the peasant, the "pinnacle of the nation" of the early times of the Republic - constitutes the initial raw stage in the civilization process of citizens.

3. Certainly in the 1930s, there already were procedures for the territorialization of differences, as Marie-Hélène Sauner-Nebioğlu (1995) explains in the introduction to her book, citing the example of some songs whose distinct characteristics are attributed to departmental differences (it is the case of the aşı for example), each of which the object of its own folklorization.

4. As in the collection Books of the country [Memleket Kitaplarl], published by the Istanbul publishing house İletişim.

5. See the Special Issue of the European Journal of Turkish Studies (2005/2) devoted to these associations: http://ejts.revues.org/359.

6. Anatolia, until recently connoted very negatively (in terms of backwardness or obscurantism), tends to become a sanctuary of national values to be preserved in an increasingly urbanized and internationalized Turkey.

7. The term bölge refers so much to division that many often prefers that of yöre, whose connotations are more strictly cultural or even folkloric. Yöre initially referred to the "near surroundings": its meaning has expanded to cover now the one of bölge (eg. in 1971, the establishment of "priority development zones" kalkınmada önceliklik yöreler).

8. The naturalization of territorial disparities is an obstacle which the weight of German geographers in the institutional construction of Turkish university geography has undoubtedly strengthened. The regional divisions elaborated since the 1930s have a strong naturalistic base, and more precisely climatological. The work of Ziya Payzın (1967), although a pioneer on the issue of regional imbalances, reflects this tendency to naturalize differences, with certain comments on the influence of climate on "family lifestyle" having dignified accents of Montesquieu (see Erinç 1958).

9. That began in 1911 for the Ottoman Empire with the Tripolitan War against Italy and continued through the Balkan wars in 1912-13.

10. Exchange between nascent Turkey and Greece on "religious" bases, and supervised by the League of Nations.

11. See Issues of the European Journal of Turkish Studies (2008/7, 2011/12 and 2013/16) devoted to demographic engineering.

12. It was successively the East (şark then Doğu), the region (Bölge), and the Southeast (Güney Doğu). Cf. Emin Bozarslan (1966).

13. The only regional administration experience is at the level of the military and police, since it involved a whole "region" which was placed under exceptional status (OHAL) between 1987 and 
2001, given the everyday violence that prevailed there. The current challenge is therefore to emerge from a vision of the region that is still exclusively related to safety.

14. The law no. 1994 of 16/6/1994, which amends the founding law of this institution (1960), introduces however some modifications regarding care for the territory: reference to zones of priority development (Part 1, article 2) and reference to the "Regional Development Directorate" (Part Two, Article 14).

15. This period remains a permanent reference for a certain number of actors and observers who consider that the State's voluntarism proudly displayed during these years has since blunted under the assaults of a liberalism tending to relativize the role of the State. (Erder et al., 2003).

16. This final division, in a European perspective, defines three levels of territorial units for statistics (the NUTS or Nomenclature of Territorial Units for Statistics). Level 1 corresponds to that of the regions (there are 12), level 2 is sub-regions (26) and level 3 is that of the departments. Figure 2 shows a new regionalization, from seven regions to twelve, with the "Black Sea", "Marmara" and "Eastern Anatolia" each subdivided, with the department of Istanbul a level region 1 on its own, and a new region "Western Anatolia" being created.

17. There is, however, a more or less assertive regional consciousness in contemporary Turkey, which relies on strong identifications and self-identifications, particularly with reference to the Black Sea region [Karadenizli] with more or less positive connotations associated with these qualifications. This consciousness, most often forged through emigration, refers to an origin to construct a sometimes active imaginary community. It refers to membership, without links to political or more broadly social actions, except through the "homeland associations" taken in a federation movement with a regional reference basis (the evolution has been noted for Black Sea village or district associations, see Pérouse 2005). The mobility of populations in Turkey, which takes very different forms according to moments and social environments, would be the origin of a change in the perception of territory.

18. In particular the book by Ashword and Voogd (1990), Selling the city: Marketing Approaches in Public Sector Urban Planning.

19. Adherence to urban transformations has been less studied in the current literature than the phenomena of contestation. These include the work of Sevinç Doğan (2016).

20. The territory is conceived as an "arrangement of material and symbolic resources capable of structuring the practical conditions of the existence of an individual or of a social collective and of informing this individual and this collective on his own identity" (Debarbieux 2003: 910). In the 1990s, for example, a project such as "Spike city / Başakşehir" (Pérouse 2010).

21. "The promoters in charge of widening and renovating it had decided to build the sides of the avenue in modern style, but the Chinese municipality decided that buildings should be built in a pastiche Chinese style" (Sanjuan 2013).

22. The recent migratory agreement with the European Union reminds us, if need be, that population flows are not fluid: synapses and crossing points sometimes become more flexible, sometimes more rigid, depending on political decisions and geopolitical tensions. These impediments concern, of course, external borders, but also internal circulation in Kurdishdominated regions, with impacts on the functioning and organization of territories (Sönmez 2008, Thevenin 2014).

23. For the central government, territorial control involves a significant public investment in military technology - evidenced by the recent launch of the Göktürk 1 satellite from the Kourou base in Guyana at a cost of 261.5 million euros. At a time when large-scale mapping of the territory is still not accessible to the civil sphere, the latter allows the acquisition of highresolution images without geographical limits (which has not failed to stir Israel's sharp condemnation). 


\section{AUTHORS}

\section{SÉGOLÈNE DÉBARRE}

Université Paris I Panthéon Sorbonne

UMR 8504 Géographie-cités

\section{JEAN-FRANÇOIS PÉROUSE}

Institut français d'études anatoliennes, Istanbul 